\title{
Globalizing Corporate Environmentalism? Convergence and Heterogeneity in Indian Industry
}

\author{
Richard Perkins
}

C Springer Science + Business Media, LLC 2007

\begin{abstract}
What explains the recent emergence of corporate environmentalism in developing countries? Why have certain firms surpassed others in greening their activities? This article situates the uneven dynamics of corporate greening within a theoretical framework of convergence, firm specificity, and heterogeneity. Through a comparative analysis of firms in three sectors - automobiles, steel, and power-of the Indian economy during the past two decades, I show that corporate greening is rooted in processes of growing international political engagement, market integration, and transnational social communication. Together, these processes have unleashed various economic and sociological convergence dynamics, which have led firms in India to adopt more environmentally sound innovations and performances increasingly similar to those found in many developed countries. Yet firms' connectedness to external pressures fostering "upward" convergence varies, as do their internal capabilities to respond to them. Heterogeneity in these internal and external variables, and the firm-specific strategies linking them, accounts for much of the unevenness in patterns of corporate environmentalism observed in India.
\end{abstract}

Keywords Corporate environmentalism - Convergence - Globalization · Heterogeneity $\cdot$ India

\section{Introduction}

While much of the early work on corporate environmentalism focused on developed economies, a growing number of studies have begun to investigate the role played by firms as agents of environmental sustainability in developing ones. This work has revealed an emergent, albeit mixed, picture of corporate greening (Dasgupta 2000; Jenkins 2000; Ruud 2002; Utting 2002). During the past two decades, some firms

R. Perkins $(\bowtie)$

Department of Geography and Environment, London School of Economics and Political Science, London, UK

e-mail: R.M.Perkins@1se.ac.uk 
have made considerable investments in more environmentally sound innovations and performances. Other firms have made little or no progress toward sustainability.

What explains the recent emergence of corporate environmentalism in developing countries? Why have certain firms surpassed others in greening their activities? Previous work has largely approached these questions within a static and reductionist framework. That is, scholars have sought to explain corporate greening in terms of the presence of various proximate drivers, and variation in greening across firms with reference to constraints. Among the former, studies have pointed to the role of regulatory pressure from governments and civil society, together with market incentives in terms of improved cost competitiveness and access to environmentally demanding customers (Jenkins 2000; Rock 2002; Utting 2002). In terms of the latter, barriers have been identified primarily as technological and financial in nature, with firms' capabilities limiting their ability to improve environmental performance (Dasgupta 2000; Sawhney 2004).

No doubt, these studies have proved instructive. Yet their explanation of trends and patterns of corporate greening in developing countries is underspecified. Two issues, in particular, have been inadequately addressed. First, previous studies have had surprising little to say about the origins of corporate environmentalism in developing countries, or why it is emerging at much lower levels of income than developed economies. Beyond references to economic liberalization (e.g., see Jenkins 2000; Rock 2002), they have failed to theorize, specify, and identify the underlying pathways through which corporate greening has arisen. Second, past research has paid insufficient attention to the role of external pressures, and their relationship to internal constraints, in explaining uneven patterns of corporate environmentalism (e.g., see Dasgupta 2000). In doing so, it has ignored a body of literature, which suggests that corporate behavior is often shaped by the strategic interplay between internal and external opportunities, incentives, and constraints (Oliver 1997; Hoffman 2001).

This article seeks to address these gaps. To this end, I build on and expand traditional explanations of corporate greening predicated solely on proximate drivers and barriers, situating them in a broader theoretical framework of convergence and heterogeneity. I locate the growth of corporate environmentalism in terms of developing countries' growing enmeshment in political, economic, and social processes at the international level, which have exposed domestic actors to a range of economic and institutional/sociological pressures fostering cross-national convergence in environmentally sound technologies, operating practices and performances. However, firms' connectedness to these institutional pressures varies, as do their internal resources and capabilities. Heterogeneity in these variables and the firmspecific corporate strategies linking internal resources and external pressures are largely responsible for unevenness in patterns of corporate environmentalism in developing countries.

To explore these ideas, I examine evolving patterns of corporate environmentalism among firms in India, in the automobile, steel, and power sectors. During the past two decades, firms in these sectors have invested in more environmentally sound technologies and organizational practices, leading to improvements in environmental performance. Yet, as witnessed in many other developing countries, the degree of greening has varied among firms, both within and between the sectors. 
Explaining these investments in corporate greening and their unevenness forms the central objective of this article.

The rest of the article proceeds in six sections. First, I begin by exploring the theoretical background to the study, focusing on possible underlying explanations for observed patterns of corporate environmentalism in developing countries. Second, I outline the research design and methodology, and explain the choice of case-study sectors. Third, I document recent trends and patterns of corporate environmental behavior in the case-study sectors. Fourth, I attempt to explain recent dynamics of corporate environmentalism, identifying the proximate drivers of greening, before going onto examine the role played by various underlying nondomestic influences. I then explore the reasons for the uneven pattern of corporate greening. Finally, I conclude in section six and discuss the wider implications of the findings.

\section{Theorizing the Dynamics of Corporate Environmentalism}

\section{National Income-based Explanations and Their Shortcomings}

What might account for recent improvements in corporate environmental performance in developing countries? While previous studies have identified various proximate drivers of developing-country corporate environmentalism, they have failed to adequately explain the origins of these drivers. One possible underlying explanation is that corporate greening in developing countries is the result of concurrent, modernizing dynamics (Bennett 1997). That is, domestic firms are following in the footsteps of their counterparts in developed ones by investing in more environmentally sound innovations, but are doing so independently. A popular idea, encapsulated by the so-called environmental Kuznets curve (EKC) hypothesis, is that such ecologically modernizing investments go hand-in-hand with economic growth (Grossman and Krueger 1995). As countries become richer, popular demands for improved environmental quality rise. In turn, this evokes a response from indigenous political actors, leading to the introduction of new and more stringent environmental regulations. Heightened demand from customers, citizens, and nongovernmental organizations (NGOs) also stimulates firms to take environmental issues more seriously. At the same time, greater wealth provides firms with more resources to invest in environmentally sound innovations and the technological capabilities to effectively master these innovations.

To be sure, elements of this Kuznets-type story resonate with the proximate drivers of corporate environmentalism identified in previous work in developing countries. Various studies have pointed to growing pressure from communities, which have prompted firms to address their local environmental impacts (Hettige et al. 1996; Dwivedi 1997; Blackman et al. 2004). They have also documented how government regulations have encouraged domestic companies to improve their environmental performance (Jenkins 2000; Shin 2004). More recently, studies have drawn attention to "green" supply chain management practices, with firms in developing countries increasingly adopting environmental management practices in response to pressure from business customers (Matouq 2000; Rock 2002; Christmann and Taylor 2006). 
The idea that income is an important determinant of corporate environmentalism also receives support from large-N, statistical evidence. Recent econometric studies have shown that wealthier countries tend to have more stringent environmental regulations, diffuse environmentally sound technologies more rapidly, and have a wider uptake of environmental self-regulatory codes (Reppelin-Hill 1999; Dasgupta et al. 2001; Neumayer and Perkins 2004; Perkins and Neumayer 2005). Additionally, it is worth noting that the emergence of corporate environmentalism in several developing countries has coincided with a period of renewed economic growth.

While intuitively plausible, if income-driven domestic dynamics were really responsible for corporate greening in developing countries, then two observations should logically follow. First, we should expect corporate environmentalism to emerge in developing countries at similar levels of income to developed economies in the 1970s, the time during which firms in the latter began to make significant environmental investments. Second, we should expect the character of corporate environmentalism to differ between developed and developing countries, because they are evolving independently. As I will demonstrate, both of these predications fail to stand up to scrutiny.

\section{Global Convergence Theories}

This article explores a competing underlying explanation, namely, that corporate greening in developed economies has influenced similar dynamics in developing countries (Frank et al. 2000; Hilton 2001; Grubb et al. 2002). In short, the recent wave of environmental investments by firms in developing countries may be part of a wider process of globalizing corporate environmentalism. In making this argument, I do not seek to challenge the proximate drivers of corporate environmentalism identified in previous studies (Jenkins 2000; Blackman et al. 2004). Rather, I seek to complement and extend these works, by providing fresh insight into the underlying dynamics animating these (and other) proximate drivers. Unlike the Kuznets-type explanation outlined above, which focuses on economic growth, I maintain that it is international exposure, contact, and external influence that have underpinned corporate environmentalism. My central expectation is that the rise of corporate greening in developing countries should have accompanied deepening globalization, in the sense of growing interconnections and interdependence with other countries that comprise the international community. Moreover, influenced by external developments, I expect the content of corporate environmentalism-i.e., in terms of technologies, practices, and performances - in developing countries to demonstrate growing similarities with developed ones over time.

My argument draws from and combines two broad streams of convergence literature. The first comprises economic theories of convergence (Gong and Keller 2003). According to these approaches, income disparities between countries should narrow over time as comparatively less productive (i.e., developing) countries adopt and diffuse technology innovated in comparatively more productive (i.e., developed) economies. Primary among the mechanisms for convergence are trade and foreign direct investment (FDI), which are said to increase both the supply of and demand for new technology via competitive pressures. Although not previously applied to corporate environmentalism, economic theories of convergence are nevertheless 
instructive, in the sense that investments in more modern, "eco-efficient" technologies are motivated by cost-savings (Warhurst and Bridge 1997). Specifically, they would predict growing convergence in environmental technologies, practices, and performances between developed and developing countries, as firms in developing countries are exposed to increased competition from firms in developed countries. This expectation is consistent with large-N, statistical studies that find that new, more environmentally sound technologies and practices have been more rapidly adopted and diffused in countries more open to international trade (Reppelin-Hill 1999; Dasgupta et al. 2001; Neumayer and Perkins 2004; Perkins and Neumayer 2005).

A second stream of convergence literature is rooted in institutional theory. Although broad and diverse, a unifying feature of institutional approaches is the idea that actors are embedded in wider institutional environments - so-called institutional fields - which support, constrain, and influence behavior (DiMaggio, and Powell 1983; Delmas, and Toffel 2004). Through various interorganizational networks, linkages, and connections, it is suggested that actors are subject to isomorphic pressures, with the result that organizational practices and structures tend to homogenize within particular fields. I argue that isomorphic processes are contributing to the international diffusion of corporate environmentalism from developed to many developing countries.

In a seminal contribution, DiMaggio and Powell (1983) outline three institutional mechanisms that create homogeneity: coercive, mimetic, and normative. Coercive pressures arise where actors are compelled or persuaded to adhere to certain practices by external market, government, or civil society actors. Mimetic dynamics arise where actors imitate the behavior of others under conditions of uncertainty. Finally, normative pressures refer to the influence of political elites, advocacy groups and knowledge-based communities who are instrumental in prescribing and diffusing norms of legitimate practice.

Although institutional approaches have predominantly been applied to understand the spread of corporate environmental practices at the national level, a growing number of scholars have also documented - or else hypothesized-how isomorphic mechanisms may transcend national borders via various transnational linkages to foster cross-national environmental convergence (Levy and Kolk 2002). Among other things, they have highlighted how trade ties potentially lead to the transmission of coercive pressures from high-regulating to low-regulating countries, fostering convergence in private or public environmental standards through a trading-up effect (Mendel 2002; Perkins and Neumayer 2004; Potoski and Prakash 2004). They have also described how mimetic-type processes may operate across borders, as civil, market, and state actors emulate and replicate more ambitious environmental practices and policies previously adopted in other countries (Mendel 2002; Tews et al. 2003). Scholars have also described how international contact via international and transnational linkages has created demand for environmental protection through the spread of norms of environmentalism (Frank et al. 2000).

My explanation of corporate greening builds on, combines, and extends the above theories of convergence to provide a more completely specified account of how heightened international and transnational linkages have led to the emergence of corporate environmentalism in developing countries. More specifically, my unique 
contribution is three-fold. First, I go far further than previous work in identifying the underlying pathways through which nondomestic exposure, contact and engagement have led to the transfer, adoption and diffusion of corporate environmentalism. Previous studies have provided a rather fragmented picture of these dynamics. Individual contributions have typically drawn attention to how one or possibly two external forces (e.g., coercion) contribute to the spread of environmental innovations and have mostly restricted their focus to external influence arising from economic linkages. This article advances on these works by, first, considering the influence of a larger and more diverse set of potential economic and sociological forces and, second, exploring the role of both economic and noneconomic forms of global interconnection.

A second major contribution of this article is to bridge existing literature on corporate greening in developing countries, which has largely focused on various proximate drivers of corporate greening, and emerging work that locates a role for convergence dynamics in the global spread of environmental innovations. To this end, I trace the direct and indirect ways through which nondomestic convergence forces contribute to the decision by firms to adopt more environmentally sound technologies, practices and performances. Although previous work has documented how heightened global exposure, engagement and interdependence have led to the spread of various environmental innovations (e.g., public policies) across borders, these studies have made little progress in elaborating how these processes translate into rising corporate environmentalism in developing countries. This study attempts to begin to fill this gap.

A third major contribution of this article is to advance understanding of the uneven dynamics of corporate greening in developing countries. Going beyond a simple restatement of the idea that firm and/or sectoral characteristics matter, I seek to clarify how they matter in shaping differences in the degree of corporate greening. I turn to this issue in the next section.

\section{Heterogeneity in Corporate Greening}

While convergence-type explanations offer promising insights into the emergence of corporate environmentalism in developing countries, they provide little explanation for variations in corporate greening. Put simply, why do certain firms in the same domestic institutional field surpass others in adopting more environmentally sound innovations? Unfortunately, to the extent that the convergence literature has examined heterogeneity, it has largely done so at the cross-national scale of analysis (Dore et al. 1999; Argent 2002). Much neglected by this literature is the lower level context. Little is said about how firm or sectoral characteristics might impede, facilitate, and modify patterns of cross-national convergence or how internal and external pressures intersect (Oliver 1997). In the context of corporate environmentalism, the literature offers some tantalizing clues. Certain studies have pointed to differences in firms' connectedness to market and regulatory pressures (Mercado 2000; Vogel 2000; Jeppesen and Hansen 2004). Other studies have highlighted the importance of technological and financial capabilities (Dasgupta 2000), while still others have focused attention on corporate strategies (Delmas and Toffel 2004). 
Although frequently discussed independently, it is possible that these three determinants may in fact be related (Oliver 1997). According to the resource-based perspective, corporate strategy, choices and behavior are strongly influenced by internal resources and capabilities, which provide the basis for firms' competitive advantage (Peterlaf 1993). Corporate strategy, in turn, will define firms' market positioning in terms of participation in domestic or export markets, low value-added or high value-added product sectors, and so forth. To the extent that firms' market positioning affects their exposure to external pressures creating homogeneity, resources and capabilities are likely to prove decisive in determining the degree of corporate environmentalism amongst firms.

Combining insights from cross-national convergence and resource-based theories, I predict that differences in the degree of corporate greening will depend on firms' internal resources and exposure to external pressures. Firms that are more connected to international economic and sociological pressures are likely to go further in greening their activities. Similarly, firms with greater capabilities are more likely to invest in corporate environmentalism, and therefore move closer to levels of environmental performance found in developed economies. Equally significant, I expect firms with superior resources and capabilities to be more likely to strategically engage in market sectors and contexts where they are more exposed to external pressures fostering environmentally beneficial investments.

\section{Research Design and Methodology}

The empirical focus here are firms in three industrial sectors, namely, automobiles, steel, and electricity generation. Summary descriptions of the three sectors are provided in Table 1. Although the primary unit of analysis is the firm, I also consider variations at a sectoral level. Since firms in the same sector are often confronted by similar pressures, opportunities, and constraints, it makes sense to aggregate to the sectoral level in examining several sources of convergence and heterogeneity in corporate greening.

India provides a fitting setting for the present research for two key reasons. First, the country is host to many diverse firms in each of the three case-study sectors, and provides a large population for investigating the patterns, mechanisms, and determinants of corporate environmentalism. Second, the country shares important characteristics with other low-income countries, suggesting that observed dynamics may be indicative of trends elsewhere. Thus, it has a similar history of post-World War II import substituting industrialization policies, and has followed in the footsteps of other developing countries by instituting neoliberal reform policies, including measures to reduce barriers to FDI and trade.

India has also experienced a similar trajectory of worsening environmental quality experienced by many other low-income economies in recent decades (Jenkins 2000; Economy 2004). Much like these countries, the Indian government has adopted a series of environmental regulations to combat environmental degradation. As detailed later, a growing number of firms in India have also begun to invest in (more) environmentally sound innovations. Studies have documented similar investments by more dynamics firms in other rapidly industrializing developing 
Table 1 Characteristics of the case-study sectors

\begin{tabular}{|c|c|c|c|}
\hline & Main actors & Recent history & Markets \\
\hline Automobile & $\begin{array}{l}10 \text { foreign transnationals/ } \\
\text { joint ventures; } 3 \\
\text { indigenous firms. }\end{array}$ & $\begin{array}{l}\text { Until } 1993 \text {, sector comprised } \\
3 \text { indigenous firms, and } 1 \\
\text { joint venture. Neoliberal } \\
\text { reforms followed by the } \\
\text { entry of transnational } \\
\text { vehicle manufacturers. }\end{array}$ & $\begin{array}{l}\text { Since liberalization, high } \\
\text { levels of competition in } \\
\text { product markets. Negligible } \\
\text { imports. }\end{array}$ \\
\hline Steel & $\begin{array}{l}3 \text { large-scale integrated } \\
\text { producers; } 3 \text { medium-scale } \\
\text { ("greenfield") semi- } \\
\text { integrated producers; } 38 \\
\text { small-scale electric arc } \\
\text { producers; ca.700 small- } \\
\text { scale induction furnaces. } \\
\text { All plants owned by } \\
\text { indigenous firms. }\end{array}$ & $\begin{array}{l}\text { Majority of capacity prior to } \\
1991 \text { created in the public } \\
\text { sector. Liberalisation } \\
\text { removed restrictions on } \\
\text { ownership, capacity } \\
\text { addition and lowered } \\
\text { import restrictions. } \\
\text { Accompanied by } \\
\text { modernisation of existing } \\
\text { integrated producers and } \\
\text { creation of new semi- } \\
\text { integrated and electric arc } \\
\text { furnace plants. }\end{array}$ & $\begin{array}{l}\text { Competition intense for } \\
\text { integrated and semi- } \\
\text { integrated producers, both } \\
\text { from domestic and foreign } \\
\text { sources; limited foreign } \\
\text { competition for induction } \\
\text { furnace producers. }\end{array}$ \\
\hline Power & $\begin{array}{l}\text { Three main actors: } 28 \text { state } \\
\text { electricity boards (SEBs)/ } \\
\text { electricity departments; } 2 \\
\text { central sector generating } \\
\text { companies, including } \\
\text { National Thermal Power } \\
\text { Corporation (NTPC); and } \\
\text { private producers, } \\
\text { comprising private utilities } \\
\text { and numerous indigenous } \\
\text { and foreign independent } \\
\text { power producers (IPPs). } \\
\text { Actors account for ca.55\%, } \\
\text { 34\%, and } 11 \% \text { of total } \\
\text { generation. }\end{array}$ & $\begin{array}{l}\text { State-owned SEBs, created in } \\
\text { late } 1940 \text { s, were responsible } \\
\text { for the bulk of new capacity } \\
\text { after independence. Central } \\
\text { sector generating firms } \\
\text { created in the } 1970 \text { s to } \\
\text { ameliorate emerging power } \\
\text { supply deficit. Reforms of } \\
1991 \text { permitted the entry of } \\
\text { IPPs for sale of electricity to } \\
\text { the grid, although actual } \\
\text { capacity addition has been } \\
\text { far below expectations. }\end{array}$ & $\begin{array}{l}\text { Until recently, electricity } \\
\text { tariffs of SEBs set by state } \\
\text { governments. } \\
\text { Arrangements for } \\
\text { remunerating IPPs } \\
\text { generally based on a } \\
\text { levelised tariff. Weak } \\
\text { finances of SEBs meant } \\
\text { that comparatively few IPP } \\
\text { projects, especially large } \\
\text { ones, commissioned. }\end{array}$ \\
\hline
\end{tabular}

Source: Author

economies (Garcia-Johnson 2000; Jenkins 2000; Utting 2002), suggesting that current trends in corporate environmentalism witnessed in India are far from unique.

The three case-study sectors were purposefully chosen because they are economically significant, (potentially) pollution-intensive sectors, in which both developed and developing countries participate. They were also selected to have a representation of firms that differ in their source impacts, product markets, ownership, and degree of influence. This is important for two reasons. First, the diversity of firms among the sectors provides a broader test of claims regarding converging trajectories of corporate environmentalism. Second, sectoral and firm variability better enables us to identify the factors that are driving or inhibiting corporate environmental change.

Fieldwork during three visits to India between March 2000 and August 2005 provided the empirical data for this study. The research, undertaken entirely by the 
author, involved in-depth, semi-structured interviews with a range of domestic stakeholders. These comprised interviews with business and environment managers from firms in the passenger car $(N=9)$, steel $(N=12)$ and electricity generation $(N=15)$ sectors. Their responses were supplemented-as well as cross-checked-with interview data from: (1) suppliers of technologies and environmental management services $(N=6)$; (2) government ministries and departments $(N=7)$; (3) environmental regulators at the central and state levels $(N=6)$; $(4)$ multilateral $(N=3)$ and bilateral donors $(N=5)$; and (5) environmental nongovernmental organizations $(N=5)$. Additional data originated from a range of published and unpublished literature.

I define corporate environmentalism broadly to include the deployment of technologies and organizational management practices that improve a firms' environment efficiency, ${ }^{1}$ whether for environmental or nonenvironmental reasons. I opt for this less restrictive definition since, as previously documented in the literature, reductions in firms' environment intensity derive from a range of technological and operational changes, and are driven by a range of motives (Howes et al. 1997).

\section{Corporate Environmentalism: Sector and Firm Trends and Patterns}

\section{Automobile Industry}

India's automobile industry entered the 1980s producing vehicles that were not only comparatively technologically obsolete, but also highly fuel inefficient and heavily polluting (Venkataramani 1990; Sorabjee 1997). As an example, Sharma and Roychowdhury (1996: 45) report that the base-engine in Hindustan Motors's iconic Ambassador changed little from 1953 to 1986. This situation owed much to India's closed, autarkic policy regime, which restricted competition, technology transfer, and funds for modernization investments. Over the past two decades, the environmental performance of cars manufactured in the country has improved dramatically, largely by using more advanced process (i.e., base-engine) and endof-pipe (i.e., catalytic converter) technology.

The greening of the passenger car sector was led by foreign transnational vehicle manufacturers. This began in the early 1980s with the creation of Maruti Udyog, a joint venture company between the Government of India and Suzuki Motors of Japan. Maruti's first vehicle, the 800, was twice as fuel efficient as domestic models such as Hindustan Motors's Ambassador (Venkataramani 1990: 13). More significant was the entry of major auto manufacturers in the early to mid-1990s. ${ }^{2}$ Most of the transnational auto majors introduced engine technology with higher emissions performance than offered by domestic producers at the time, or required by domestic regulations. For example, both Daewoo and Hyundai entered the market with multipoint fuel injection (MPFI), a technology that allows for greater control

\footnotetext{
${ }^{1}$ We define environment efficiency as the amount of energy and resource used, as well as the pollution and waste generated per unit of production or, in the case of the automobile sector, consumed.

${ }^{2}$ Firms wishing to sell cars in India have been forced to set up local manufacturing plants.
} 
over combustion, reducing engine-out emissions. Similarly, Ford and General Motors came in with single-point fuel injection, which, although not as advanced as MPFI, is capable of lower engine-out emissions than the carburetor-based engines used by domestic vehicle manufacturers at the time.

With the introduction and subsequent tightening of the so-called Bharat emission standards since the late $1990 \mathrm{~s}$, the domestic vehicle manufacturers also began to invest in more environmentally sound technologies. Among others, manufacturers such as Hindustan Motors upgraded their carburetor-based base-engine with MPFIbased alternatives. For certain models, they even acquired entirely new base-engines from foreign vendors such as Renault, originally designed for use in high-regulating markets (in Europe, etc.).

\section{Steel Industry}

The majority of India's steel firms also emerged from the period of importsubstituting industrialization characterized by low levels of process efficiency and high pollutant emissions (Mittal 1996; Kher 1997). During the past 20 years, significant investments have been made in (more) environmentally sound practices within the sector. However, the degree of corporate greening has been highly uneven.

At the one extreme, some semi-integrated "greenfield" producers have leapfrogged ahead of their developed country counterparts, at least in terms of the environment efficiency of their process technologies. Promoters have incorporated various clean steel-making technologies, often sourced from leading multinational vendors (e.g., Mannesman-Demag Hüttentechnik of Germany). Thus, Essar Steel opted for more environment-efficient, directly reduced iron (DRI)-electric arc furnace (EAF) production. While Jindal Vijayanagar Steel Ltd (JVSL) and Ispat Industries have made use of a range of innovative process technologies - COREX smelting reduction, CONARC steelmaking, and thin-slab casting - with high levels of process-integrated environmental performance (Chandekar 1998). Evidence suggests that these new greenfield plants achieve levels of energy efficiency comparable to recently commissioned units in developed economies (Bode et al. 2000).

The semi-integrated producers have also adopted green organizational innovations. Essar Steel, for example, operates an in-house "Environment, Risk and Insurance Department," charged with ensuring that the company's environmental policy is effectively implemented. Following Essar Steel's lead, JVSL, Jindal Steel and Ispat Industries have obtained ISO 14001 certification, the internationally recognized standard for EMSs.

At the other extreme, lie numerous small-scale "secondary" steel producers, which use electric arc, or more commonly, induction furnace technology. Although many of these firms have made efforts to upgrade their process equipment, their materials and energy efficiency remains poor (Athreye 1999). Moreover, many producers lack adequate pollution-control technologies, with a significant share of induction furnace-based plants lacking even basic end-of-pipe equipment (Office the Deputy Commissioner of Iron and Steel 1999).

In between the above are the large-scale integrated producers, which, over the past two decades, have invested heavily in modernizing their aging plants. The two 
main "primary" producers, SAIL and $\mathrm{TISCO}^{3}$ have progressively replaced polluting, inefficient process units (e.g., open hearth furnaces) with more modern, environment-efficient alternatives (e.g., basic oxygen furnaces). Many pollution control devices have been installed at their respective plants (SAIL n.d., various years; Tata Steel various years). For example, SAIL claims that a total of 805 air pollution and 225 water pollution devices were installed during the 1990s, accounting for $8-10 \%$ of total modernization expenditures (SAIL n.d.). Both companies also established dedicated environmental management departments and plant-level environmental management systems during the 1990s. In June 2000, TISCO became the first integrated mill in India to obtain certification to ISO 14001. More recently, production units at SAIL's Salem and Rourkela plants were certified to ISO 14001.

Existing data suggest that these investments have brought significant improvements in environmental performance. Specific energy consumption across SAIL's four integrated plants, for example, fell from $8.99 \mathrm{GCal} / \mathrm{tcs}$ in 1991-1992 to 7.28 GCal/tcs in 2004-2005, bringing it closer to levels among developed country integrated producers of around 4.75-5.0 GCal/tcs. From 1994-1995 to 1999-2000, TISCO dramatically reduced suspended particulate emissions (SPM) from 9.07 to $2.02 \mathrm{~kg} / \mathrm{tcs}$; and the water pollution load fell from 1.77 to $0.211 \mathrm{~kg} / \mathrm{tcs}$ (SAIL various years; Tata Steel various years).

\section{Power Sector}

Although less widespread, corporate greening has also occurred within the electricity generation sector. Two actors have made major investments in (more) environmentally sound generation technologies and organizational practices. The first is a central, government-owned company, the National Thermal Power Corporation (NTPC), India's largest generator. All of its plants commissioned during the past 20 years have been fitted with emissions control equipment capable of exceeding statutory emission norms (NTPC 2006). More recently, NTPC has also pioneered the adoption of more efficient generating technology, including supercritical pulverized coal units, widely regarded as a "clean coal technology" (Ghosh and Abbi 2000). NTPC has established internal structures to manage its environmental performance, including energy conservation groups at each of its generating stations, a centralized and plant-level environmental management groups, and a dedicated ash management division. All of NTPC's 24 plants, bar one, are certified to ISO 14001. The company has also committed itself to the principles of the Global Compact, the United Nations initiative designed to promote corporate social responsibility.

A second set of actors contributing to corporate greening have been independent power producers (IPPs) - generating firms that entered the market following reforms in the early1990s, allowing domestic or foreign firms to set up plants to sell electricity to the grid. Their environmental significance is two-fold. First, domestic IPPs have commissioned many small-scale renewable projects-notably, wind, mini-

\footnotetext{
${ }^{3}$ SAIL (Steel Authority of India Ltd.) is India's largest steel producer, operating four publicly owned plants, variously commissioned between the 1950 s and 1970 s; TISCO is a privately owned company that operates a single plant which dates back to the 1910s.
} 
Table 2 Patterns of corporate greening in the case-study sectors since the early 1990s

\begin{tabular}{|c|c|c|c|}
\hline & Technological & Organizational & Performance \\
\hline Automobile & $\begin{array}{l}\text { Significant upgrading in } \\
\text { base-engine and end- } \\
\text { of-pipe (i.e., catalytic } \\
\text { converters) technology } \\
\text { since early 1990s. A } \\
\text { number of transnational } \\
\text { manufacturers first to adopt } \\
\text { more environmentally } \\
\text { sound base-engine } \\
\text { technology and catalytic } \\
\text { converters. With the } \\
\text { introduction of Bharat } \\
\text { standards since the late } \\
\text { 1990s, differences between } \\
\text { indigenous and } \\
\text { transnational vehicle } \\
\text { manufacturers have } \\
\text { narrowed or disappeared. }\end{array}$ & $\begin{array}{l}\text { Not applicable since focus is } \\
\text { on products rather than } \\
\text { processes. }\end{array}$ & $\begin{array}{l}\text { Significant improvement in } \\
\text { the emissions performance } \\
\text { of new vehicles. Stringent } \\
\text { emissions testing } \\
\text { procedures by government } \\
\text { mean that all new vehicles } \\
\text { generally compliant with } \\
\text { standards. Major } \\
\text { improvements in fuel } \\
\text { efficiency across the sector. }\end{array}$ \\
\hline Steel & $\begin{array}{l}\text { Established integrated } \\
\text { producers (i.e., SAIL and } \\
\text { TISCO) invested heavily in } \\
\text { replacing/retrofitting } \\
\text { polluting process units, as } \\
\text { well as adding new end-of- } \\
\text { pipe technologies. } \\
\text { Modernisation incomplete, } \\
\text { and some older, polluting } \\
\text { process units remain. Semi- } \\
\text { integrated producers have } \\
\text { adopted advanced, energy, } \\
\text { and resource-efficient } \\
\text { process technologies, as } \\
\text { well as a range of end-of- } \\
\text { pipe equipment. Some } \\
\text { upgrading, but process } \\
\text { technologies used by many } \\
\text { small-scale electric arc and } \\
\text { induction furnace producers } \\
\text { remain inefficient, and end- } \\
\text { of-pipe technologies often } \\
\text { inadequate. }\end{array}$ & $\begin{array}{l}\text { Integrated producers have all } \\
\text { adopted environmental } \\
\text { management system } \\
\text { standards (i.e., ISO 14001) } \\
\text { in one or more of their } \\
\text { process units. They also } \\
\text { report environmental } \\
\text { performance data. Recently } \\
\text { established semi-integrated } \\
\text { producers have similarly } \\
\text { adopted environmental } \\
\text { management systems and } \\
\text { departments. Yet limited } \\
\text { uptake of formalised } \\
\text { environmental management } \\
\text { systems by small-scale } \\
\text { electric arc and induction } \\
\text { furnace producers. }\end{array}$ & $\begin{array}{l}\text { Integrated producers have } \\
\text { made significant reductions } \\
\text { in their air and water } \\
\text { emissions, and improved } \\
\text { their energy and resource- } \\
\text { efficiency. Yet they continue } \\
\text { to lag comparable units in } \\
\text { developed economies. Only } \\
\text { limited data on actual } \\
\text { environmental performance } \\
\text { of semi-integrated } \\
\text { producers. Energy efficiency } \\
\text { comparable with similar } \\
\text { units in developed } \\
\text { economies. Similarly, only } \\
\text { limited data on } \\
\text { environment-related } \\
\text { performance of small-scale } \\
\text { electric arc and induction } \\
\text { furnace producers, but } \\
\text { reports suggest that energy } \\
\text { and resource-efficiency lags } \\
\text { comparable units in } \\
\text { developed economies. }\end{array}$ \\
\hline Power & $\begin{array}{l}\text { Many state electricity boards } \\
\text { (SEBs) made some } \\
\text { progress in upgrading } \\
\text { process and end-of-pipe } \\
\text { technologies in their } \\
\text { plants. Yet older plants are } \\
\text { highly inefficient and end- } \\
\text { of-pipe technologies are } \\
\text { not always capable of } \\
\text { achieving regulatory } \\
\text { compliance. National } \\
\text { Thermal Power }\end{array}$ & $\begin{array}{l}\text { Only a handful of SEBs have } \\
\text { adopted standardized } \\
\text { environmental management } \\
\text { systems. NTPC has certified } \\
\text { the vast majority of its } \\
\text { plants to ISO } 14001 \text { and has } \\
\text { a dedicated environmental } \\
\text { management infrastructure } \\
\text { at headquarter and plant } \\
\text { level. Some larger IPPs } \\
\text { have formal environmental } \\
\text { management systems. }\end{array}$ & $\begin{array}{l}\text { Only limited data on the actual } \\
\text { environmental performance } \\
\text { of plants. Energy-inefficient } \\
\text { plants disproportionately } \\
\text { found among SEBs. } \\
\text { Moreover, evidence suggests } \\
\text { that many SEB plants do not } \\
\text { always comply with } \\
\text { regulatory standards. } \\
\text { Energy-efficiency of NTPC } \\
\text { plants closer to developed- } \\
\text { country standards. }\end{array}$ \\
\hline
\end{tabular}


Table 2 (continued)

\begin{tabular}{ll}
\hline Technological & Organizational \\
\hline & Performance \\
invested in comparatively & \\
energy-efficient process & \\
technologies from the & \\
outset, together with & \\
beyond-compliance end- & \\
of-pipe technology. Many & \\
smaller IPPs & \\
commissioned fuel-oiled \\
plants characterised by low \\
levels of efficiency. Some \\
larger IPPs have adopted \\
comparatively efficient \\
process technologies and \\
beyond-compliance end- \\
of-pipe technologies.
\end{tabular}

Source: Author

hydro and solar. Largely because of IPPs, the amount of grid-connected renewables has grown dramatically since the early 1990s, reaching 7,088 MW at the end of 2005 (MNES 2006).

Second, some developers of large-scale IPPs have invested in comparatively "clean" gas-fired projects. Approximately half the capacity commissioned by private generators has been gas-fired (Perkins 2005). Moreover, IPPs have opted for efficient generating technology. These include energy efficient frame " $F$ " gas turbines, used in recently commissioned plants in developed countries, e.g., Medway in the UK. Increasingly, IPP developers have also obtained ISO 14001 certification, e.g., GMR Energy, Lanco, and GVK Industries.

Beyond these firms, corporate environmentalism has been far more limited. Progress toward corporate greening has been generally slow among the state electricity boards (SEBs) - the vertically integrated utilities created in the early 1950s under the ownership and control of state governments - which account for approximately three-quarters of output. Many SEBs have sought to improve the thermal efficiency of their fossil-fueled plants, and invested in more effective pollution control devices (Govil 1998). A handful of state generators have also obtained ISO 14001 certification for their plants. Yet the environmental performanceparticularly in terms of pollution emissions and energy efficiency — of many plants in the state sector has remained poor.

\section{Explaining the Growth of Corporate Environmentalism in India}

\section{Proximate Drivers}

During the past 20 years, and particularly since the early 1990s, firms in each of the case-study sectors have made investments in technologies and practices to improve 
environmental performance. Table 2 provides a general overview of these developments. As should be clear, considerable differences exist in the extent of corporate greening, which I will return to later.

The primary concern here is why certain firms should have invested in more environmentally sound innovations. Adopting the approach taken in many previous studies (e.g., Mercado 2000), we can readily identify three proximate drivers of corporate environmentalism. One of the most influential is regulation. The introduction and subsequent tightening of standards governing tailpipe emissions was pivotal in forcing vehicle manufacturers, particularly domestic ones, to adopt more environmentally sound base-engine and catalytic converter technology. Similarly, government promulgated ambient and emission standards played a central role in stimulating significant investments by steel and power firms in end-of-pipe equipment. Statutory environmental impact assessment (EIA) procedures have ensured that the environmental specifications of new plants conform, or even exceed, environmental standards. Further enhancing government regulatory pressures have been environmental requirements imposed by multilateral development banks and developed-country commercial banks. Thus, many of the larger steel and power firms with significant foreign debt have been forced to adhere to a set of environmental conditions, many of which are more stringent than those specified under Indian law.

A second driver of corporate environmentalism is competitive market pressures. Within the steel sector, growing price competition has forced large-scale integrated producers such as TISCO to reduce energy and material input costs by replacing older, inefficient process technologies with more modern, efficient alternatives (Mytton and Lewis 1997; Mehra 2003). Market pressures to enhance cost competitiveness have additionally stimulated the adoption of EMSs - such as ISO 14001 - because they contribute to identifying and implementing efficiency improvements (interview with representative of major integrated steel producer, transnational IPP, 2000). Intensifying price competition has also encouraged firms to diversify and migrate into more profitable, differentiated product sectors. By requiring firms to adopt advanced process and product technologies, which are often characterized by superior environmental performance vis-à-vis vintage substitutes, differentiation has contributed to corporate greening. An important factor in the choice of innovative technology by promoters of recent "greenfield" steel plants, for example, was the ability of semi-integrated process configurations to produce high quality, cost-competitive steels for export markets (Chandekar 2000).

A third driver of corporate environmentalism in India has been civil society pressure. Its influence has been mobilized in three ways: involvement in public hearings, sponsors of litigation, and monitoring of transnational corporations (TNCs). Community groups and NGOs have been able to delay, or scuttle altogether, project proposals by raising objections at the public hearing stage of statutory EIA. The prospect of costly hold-ups has led many developers of larger steel and power projects to adopt a more proactive approach, incorporating beyondcompliance technologies into their plant specifications from the outset (interviews with representatives from leading NGO and foreign IPP developer, 2000).

Individual activists, community groups, and NGOs have successfully used litigation to pursue higher corporate environmental standards. This approach has 
been most far-reaching in its consequences in the passenger car sector where public interest litigation (PIL) cases launched by environmentalists were effective in catalyzing the enactment of more stringent vehicular emission standards in major cites. Finally, NGOs have performed a monitoring role, particularly in relation to foreign TNCs. Interviews with both foreign vehicle manufacturers and IPP developers revealed the threat of negative publicity by NGOs as a factor underpinning their decision to adopt voluntary environmental performance standards and codes.

\section{Underlying Dynamics: Catch-up and Convergence}

At one level, this account of proximate drivers of firm greening in India is quite familiar, with previous studies similarly locating a role for state, market, and civil society pressure (Warhurst and Bridge 1997; Jenkins 2000; Utting 2002). However, a major contribution in this article is to argue that such proximate explanations, although useful, do not go far enough because they say little about the underlying dynamics responsible for the growth of regulatory, market, and civil society pressures. What are these underlying dynamics?

I reject the idea that they are the product of domestic income growth and that the expansion of corporate environmentalism is happening independently. First, despite renewed economic growth during the past 20 years, India remains a predominantly low-income country. Moreover, while the country has a large and rapidly expanding middle class, there is very little evidence to suggest that income growth has been the decisive factor in the rise of popular demands for environmental protection (Sawhney 2004). A second reason to question whether corporate environmentalism in India is a product of independent dynamics is timing. The first wave of environmental investments by Indian firms in the 1970s broadly coincided with the rise of global environmentalism, its incorporation into international politics, and the growth in corporate environmentalism in developed economies. This process of corporate greening has accelerated with the neoliberal reforms of the early 1990s, which have increased firms' economic linkages to other countries. It would be remarkable if concurrent trends of corporate greening and greater openness to international market processes were not related.

Closer examination of the case-study sectors supports the idea of interlinkage and convergence. As predicted, the data show growing similarities in the technologies adopted by firms in India and their counterparts in developed countries. For example, before the mid-1990s, significant differences existed in the base-engine and end-ofpipe technology fitted to cars in India, on the one hand, and Europe, Japan, and the United States, on the other (Sharma and Roychowdhury 1996). Whereas all gasolinepowered vehicles manufactured in India were carburetor-based and did not feature any after-treatment technology, most of their counterparts sold in developed country markets were using MPFI-based engines, fitted with catalytic converters (Mondt 2000). Over the past decade, these differences have narrowed or disappeared altogether (Sorabjee 2005). With one exception, all of the new gasoline-powered cars sold in India today are MPFI-based and feature high performance catalytic converters, with the result that the basic (environment-relevant) technological configuration of new passenger cars resembles their counterparts in high-regulating 
markets. Many models are even fitted with the same base-engines, e.g., Hyundai's common rail diesel injection (CRDi) engine fitted to the company's Tuscan.

Similarly, recent investments by the large integrated steel producers, TISCO and SAIL, have brought the share of steel produced using more environment-efficient process technologies closer to levels found among integrated producers in developed economies. As recently as 1994, only $12 \%$ of SAIL's steel output used continuous casting technology, while the equivalent figure for TISCO was $29 \%$. Ten years later, continuous casting accounts for 64\% of SAIL's output and 98\% of TISCO's. The latter is broadly comparable with integrated plants in developed economies (IISI various years).

Within electricity generation, recent investments by IPPs in nonconventional renewables similarly mirror trends in several developed economies, where production of renewable energy has shown an upwards trajectory. From a mere 32 MW in 1991, installed capacity of grid connected wind power had grown to some 4,434 MW in 2005. Across the EU 15, the installed capacity of wind power increased from $629 \mathrm{MW}$ in 1991 to 40,317 MW in 2005 (EWEA 2005, 2006), while in the US, wind capacity increased from approximately 1,900 MW in 1991 to 6,010 MW in 2004 (EIA 2005).

A second similarity between firms in India and developed economies is in the adoption of organizational practices for environmental management and, most visibly, EMSs. EMSs originated in the U.S. in the mid-1970s, although it was not until the following decade that they began to receive wider acceptance (Steger 2000). Management systems were subsequently codified, professionalized, and standardized, first domestically, but later regionally and internationally. Foremost among these "standards" is ISO 14001. Across India, ISO 14001 certificates have grown from 257 in December 2000 to 1,250 by the end of 2004. Although far lower than in many developed economies, ${ }^{4}$ the concurrent trend toward rising certification in the two regions is nevertheless a significant one. All of India's six major steel firms have received certification for ISO 14001, either throughout their plants, or for individual process units. In terms of adoption, they differ little from their counterparts in developed economies, as well as a growing number of leading steel producers in other developing countries, the majority of which have obtained ISO 14001 certification (IISI 2005).

There is also evidence that firms have been subject to regulatory policies in India similar to ones previously adopted in Europe and the United States and that regulatory frameworks governing industrial sectors in India have followed trends in developed countries (Kuik et al. 1997). Indian vehicle emission standards adopted in 1991 were directly modeled on ECE Regulation 15.04, which was introduced in the European Economic Community in 1986 under Directive 83/351/EEC. Similarly, the staged "Bharat" emission norms are directly equivalent to standards adopted by the European Union. Figure 1 shows that emission regulations have been converging in the two markets, although Europe has retained its lead.

Likewise, an EIA has been mandatory in India since 1994 to secure project clearance in 29 potentially environmentally sensitive industrial sectors, including

\footnotetext{
${ }^{4}$ For example, Germany, the U.S., and U.K. had 4,320, 4,759, and 6,253 certifications, respectively, by December 2004. 


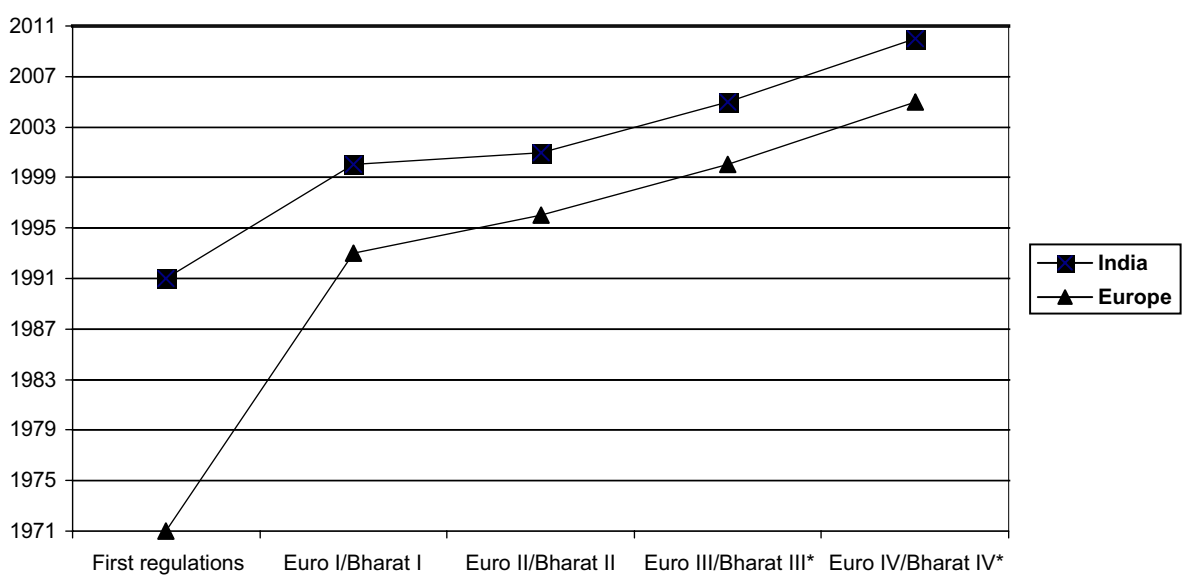

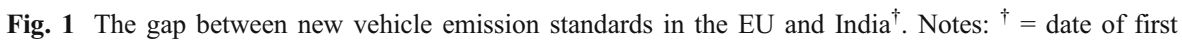
application of standard; * $* 11$ metros only. Source: Adapted from SIAM (2000) by author

steel and power. The practice of EIA was first formally adopted in the U.S. under the National Environmental Policy Act in 1969, and subsequently was introduced in more developed countries during the 1970s (Glasson et al. 1994).

The existence of growing similarity - in technologies, organizational practices, and regulatory policies - is significant. It suggests that corporate greening in India may best be understood as part of a broader process of globalizing corporate environmentalism, involving the spread of technologies, organizational practices, and regulatory policies from developed to developing countries. This global convergence explanation would account for the observation that corporate environmentalism in India has appeared at comparatively low levels of income. Put simply, rather than economic growth, the emergence of corporate environmentalism may be bound with India's growing international engagement, exposure, and integration.

\section{Mechanisms of Globalizing Corporate Environmentalism}

Consistent with this idea, I find that corporate greening in India can be traced to three broad globalizing dynamics, which have underpinned the emergence of the proximate drivers of corporate environmentalism identified above. I briefly outline below these dynamics, exploring their direct and indirect influence on patterns of corporate environmentalism.

\section{Political Globalization and the Rise of International Environmental Politics}

A first set of dynamics instrumental in catalyzing domestic corporate environmentalism originate in India's active participation in global environmental conferences, agreements, and debates since the early 1970s. Against a backdrop of rising environmental concern in developed economies, international political engagement exposed the country's political elites to normative forces prescribing environmentalism as a universally acceptable and legitimate goal (Frank et al. 2000; Haas 2002). 
Preparations for the UN Conference on the Human Environment (UNCHE) in 1972 not only served a reflexive role, helping national policymakers to acknowledge the rising scale of environmental degradation. Moreover, participation served to legitimize the natural environment as a focus of policy concern, with representatives from developed economies successfully naturalizing Northern conceptions of the nature, desirability, and necessity of environmental protection (Dwivedi 1997; Kuik et al. 1997; Najam 2005). Twenty years later, the United Nations Conference on Environment and Development (UNCED) performed a similar role, fostering the mainstreaming of sustainable development discourse. Specifically, through interaction, learning and exposure to a wide range of environmental advocacy groups, scientific knowledge communities and political representatives, the principle of environmental protection and its status as a matter of state responsibility was granted further impetus and international legitimacy (Gupta and Yunus 2004; Sawhney 2004).

These international processes of learning, socialization and internationalization are important because they have provided a stimulus for domestic environmental legislative and organizational developments. They have, in short, underpinned the regulatory driver identified above. Hence both UNCHE and UNCED were followed by a spate of new and amended environmental laws. The former served as a catalyst for the enactment of Air (1974) and Water Acts (1981), which established statutory emission limits for firms in the steel and power sectors, and led to the creation of state pollution control boards for their monitoring and enforcement. Indirectly, UNCHE was responsible for accelerating large investments made by steel and power firms in pollution control, particularly from the 1980s onward. A further wave of regulatory developments followed UNCED in 1992 (Sawhney 2004). Among others, the government added a public hearing element to the list of statutory requirements for EIA in 1997, consistent with the principles of participation enshrined in the Rio Declaration.

Yet the progressive domestic institutionalization of global environmental norms and commitments was not without instrumental purpose, serving a wider role of building international prestige, legitimacy, and acceptance (Peritore 1999). India has aspired for recognition as a major power since independence, often seeking the mantle of leadership in matters of international governance. The gradual incorporation of environmentalisms domestic polity, politics, and practice needs to be seen as part of a wider strategy for securing a reputation as a progressive member of the international community. Such reputational considerations partly explain the burst of lawmaking in the wake of the 1984 Union Carbide chemical leak, which blatantly exposed to the international community the weakness of India's environmental regulations compared to developed economies (Sawhney 2004).

Cross-national "upward" convergence in corporate environmentalism also has been advanced by mimetic processes. Against a backdrop of increased transnational communication and information exchange, environmental policy and organizational innovations adopted in developed economies have assumed a demonstrative role, providing ready-made, legitimate templates for achieving new environmental policy goals in India. Perhaps the most far-reaching example of this can be found in the emulation of emission standards previously and successfully enacted in Europe (Greenspan Bell et al. 2004). While there was some concern about the appropriateness of EU standards within the Indian context, the expediency of drawing directly 
from "tried and tested" European norms, both for regulators and vehicle manufacturers, played an important role in their replication (interviews with representatives from the Society of Indian Automobile Manufacturers, 2000, 2005). Another example comes from the power sector, where domestic actors have drawn lessons from successful U.S. and European experiences of promoting wind power. Therefore, many of the public policy initiatives adopted by central and state governments to promote private participation in wind energy - wheeling, banking, etc.- have their origins in developed economies.

\section{Economic Globalization and International Market Processes}

A second set of dynamics that have been pivotal in corporate greening is rooted in India's neoliberal reforms. By reducing restrictions on international trade, inwards investment and competition, domestic reforms have increased firms' exposure to a range of international market forces, pressures and innovations. In doing so, they have created both the demand for (more) environmentally sound technologies and organizational practices, as well as increasing their supply.

Most fundamentally, greater economic openness, international market integration, and penetration have unleashed competitive market pressures, increasing the incentive for firms to attain internationally benchmarked levels of cost competitiveness. As predicted by economic theories of convergence, growing market competition - both in domestic markets from imports, and exports markets targeted by domestic firms - provided the impetus to raise energy levels and resource productivity closer to internationally leading firms. This entailed adopting more ecoefficient process technologies, but also environmental management systems, as managers have strived to improve efficiency by emulating "best practice" organizational innovations implemented by foreign competitors.

Yet economic pressures have also fostered cross-national convergence in less obvious ways. Within the automobile industry, intensifying price competition in product markets has encouraged TNCs such as Ford, Hyundai, and Mercedes to install similar base-engines in vehicles across a range of markets in which they operate, including India. By exploiting a range of cross-market economies of scope and scale, this strategy of "commonalization" has allowed automobile manufacturers to reduce their unit research, development, and production costs (interview with representative of transnational vehicle manufacturer, 2005). Yet it has also contributed to convergence toward the highest common denominator, since engine sharing requires units to be engineered to a standard that, in broad terms, is set by the most stringent regulatory requirements in any one of the countries in which the carmaker sells it products. During the mid- to late 1990s, these requirements were higher than those in place in India.

Similar cost factors have led transnational equipment vendors - which supply a growing share of process and end-of-pipe technology to industrial firms - to offer similarly specified process equipment to their clients across the globe. In particular, the high costs of engineering different designs for different markets means that, "... for us [foreign equipment supplier] to go back a few years and sell the technology is far more expensive than to sell the technology which is our contemporary technology" (interview with a representative from a U.S. equipment supplier, 
2000). An important corollary is that larger firms in the Indian steel and power sectors have increasingly acquired technology with similar levels of processintegrated, environment efficiency to their counterparts in developed economies. Again, this has contributed to growing upward environmental convergence, even though the motives for adopting innovations have often been nonenvironmental, e. g., improving output quality.

Economic liberalization has allowed domestic firms to benefit from learning investments made in developed economies, meaning that they can purchase technologies with comparatively high levels of environmental performance at a fraction of the original research, development, and commercialization costs (Perkins and Neumayer 2005). Central to the rapid growth of wind energy in India over the past decade, for instance, has been the entry of foreign vendors. Through a series of joint ventures (e.g., Vestas RRB), these companies have brought utility scale, commercially proven wind turbine technology to India.

As well as competitive market pressures, neoliberal reforms have been instrumental in increasing firms' exposure to coercive environmental pressures from actors. Most influential in this respect have been multilateral development and developed-country commercial banks, e.g., International Finance Corporation and Deutsche Bank. Nondomestic sources of finance have assumed an increasingly important role in plant creation, expansion, and modernization against a backdrop whereby the state has withdrawn as a financier of industrial capital. As a result, rising numbers of large industrial firms have had to adhere to beyond-compliance environmental requirements. Although it is important not to overstate the coercive influence of foreign lenders, they have nevertheless been instrumental in "pulling" environmental technologies, practices, and performances of several large-scale investments in the Indian steel and power industries closer to levels found in highregulating developed economies.

Finally, exposure to international markets has stimulated mimetic dynamics, particularly among aspirant Indian multinationals such as TISCO, but also technologically and organizationally dynamic indigenous firms such as NTPC. Eager to prove their credentials as "progressive" or "global" firms among their peers, customers, and other stakeholders, such companies have imitated their larger, successful counterparts headquartered in developed countries (interview with representative from business association, 2005). Hence they have adopted many of the high-profile tools of corporate environmentalism, most notably, certified EMSs and environmental reporting. In doing so, they have sought to align themselves with, and signal their commitment to, wider norms of "responsible" business practice.

\section{Social Globalization and Civil Activism}

A third set of dynamics underpinning another of the proximate drivers of corporate environmentalism - civil society pressure - is the growth of transnational social communication. This has played an important role in catalyzing environmentalism among domestic elites. Through growing exposure to foreign media, international travel, and a wider aspiration for Western lifestyles, rising numbers of India's middleclasses have become socialized into "First World" forms and norms of environmentalism (Guha and Martinez-Alier 1997). Several middle-class environmentalists and 
NGOs - such as the Delhi-based Centre for Science and Environment-have benchmarked their environmental expectations against environmental standards in developed economies. As an example, pressure from middle-class environmentalists was pivotal in the rapid adoption of stringent vehicular emission standards (Greenspan Bell et al. 2004).

Growing transnational linkages between community groups, NGOs, and other societal stakeholder groups in different countries have also increased nondomestic and domestic coercive pressures on foreign TNCs. With modern telecommunications, etc., negative environmental impacts by TNCs operating in India can readily be exposed to wider global publics, including civil, consumer, and financial stakeholders in environmentally demanding developed countries. Actual examples where transnational environmental activism has led foreign firms to modify their environmental behavior are few. Yet the risk of large-scale environmental, financial, and reputational liabilities arising from negative environmental incidents in developing countries has nevertheless driven firms - including foreign vehicle manufacturers and larger IPP developers - to adopt common global and regional environmental standards in their Indian affiliates and subsidiaries.

\section{The Limits to Globalizing Corporate Environmentalism}

A combination of international political participation, growing market integration, and transnational social linkages have exposed domestic actors to a range of external economic and institutional/sociological pressures. In doing so, they have created forces toward homogeneity, and "pulled" environmental technologies, organizational practices and performances closer to developed economies. Some of these pressures have operated directly. Market competition, coercive dynamics, and mimetic forces acting on firms have provided various incentives, obligations, and templates for corporate greening. Indirect pressures have been equally significant. Hence normative forces - and the domestic incorporation of global norms of environmentalism - have played a pivotal role in the development of environmental regulations. These, in turn, provided much of the initial stimulus for firms' investments in more environmentally sound technologies.

While my findings provide a fillip to those who argue that greater political, economic, and social integration foster environmental upgrading, it is clear that significant variations exist in corporate greening. At a sectoral level, I find that corporate greening, and relative catch-up with developed economies, has been greatest in the passenger car sector. The least amount of environmental upgrading and catch-up has taken place across the electricity generation sector. Yet such broad comparisons conceal a great deal of interfirm variability. Differences not only exist in the degree of corporate greening between sectors, but also within them. At least in the steel and power sectors, these intrasectoral variations are as large as the intersectoral ones (see Table 2 above for more details).

Among environmental leaders, we can readily identify firms that have gone furthest toward corporate environmentalism. Within the steel sector, for example, these include semi-integrated producers. Among the established steel firms, TISCO, and to a lesser extent, SAIL, have also made significant progress in greening their 
plants. Turning to power, NTPC and a handful of larger IPP developers have led the sector in the adoption of more environmentally sound practices. Conversely, it is possible to identify numerous environmental laggards. For steel, the small-scale induction furnace producers generally fit this description, while in the power sector, the state electricity board (SEBs) and several of the small-scale, fuel-oiled IPPs lag their more technologically and environmentally progressive counterparts.

In the rest of this section, I seek to explain these differences. The objective is not to account for each difference observed between firms within and between the casestudy sectors. Rather, using a variety of examples, I attempt to identify the key determinants that have contributed to heterogeneity in corporate greening.

\section{Determinants of Heterogeneity}

\section{Exposure to External Pressures}

A central determinant shaping observed patterns of heterogeneity in corporate greening in India has been variations in firms' exposure to external forces. Broadly speaking, differences in how much connectivity and exposure to four sources of pressure have proved influential. The first is exposure to international market processes, pressures, and dynamics. For example, a unifying feature of steel firms that have invested in environmentally sound practices-including new semiintegrated (e.g., JVSL) and integrated producers (e.g., TISCO) - is their participation in export markets, or domestic markets characterized by import penetration. As detailed above, economic pressures in these markets have created incentives for firms to achieve internationally benchmarked levels of cost and quality competitiveness, and therefore upward convergence in environment efficiency. Moreover, participation in export markets has exposed firms to a range of nondomestic actors, templates, and norms of "best practice," fostering the adoption of various corporate environmental practices (e.g., EMSs, reporting, etc.) via mimetic dynamics.

In contrast, firms which have competed predominantly in domestic market sectors with limited or no import competition have been insulated from both economic and sociological pressures promoting homogeneity. A good example is small-scale induction furnace firms. With the majority of their output sold in domestic regional or local markets, they have faced few incentives to achieve international levels of cost and quality competitiveness through, for example, investments in more modern, energy-efficient process technologies (Athreye 1999).

A second important source of variability - in this case, between the passenger car sector on the one hand, and the steel and power sectors on the other-is actors' exposure to developed-country regulatory stringency. A central reason for the high degree of greening and environmental catch-up in the automobile sector is that emission standards have been copied directly from the EU. Pivotal in this respect was the judiciary's involvement. Largely removed from political considerations, the Supreme Court mandated the accelerated introduction and subsequent tightening of Bharat emission norms, principally on the grounds that similar standards have been deployed successfully in Europe. Environmental regulations governing steel and power plants have also been broadly influenced by standards previously adopted in developed economies. Yet the reluctance of government bodies-notably, the 
Central Pollution Control Board and Ministry of Environment and Forests - to impose costs on firms has meant that the majority of air and water pollution standards have remained significantly weaker than their contemporary equivalents in developed economies (interview with government regulators, 2000, 2005).

Another regulatory factor contributing to differences in corporate greening has been the implementation of environmental standards. A recurrent theme from interviews was the idea that larger, privately-owned, or recently commissioned plants faced more stringent regulatory enforcement than smaller, publicly-owned older plants. Within the steel sector, for example, evidence suggests that semiintegrated producers have often been subject to high levels of regulatory oversight, providing a strong stimulus to engineer plants to a high environmental specification. At the other extreme, small scale steel producers have typically escaped stringent enforcement of pollution standards, removing one of the few incentives for investments in end-of-pipe technologies.

A third source of variation in external pressure centers on firms' exposure to coercive environmental pressures from financial actors-itself a function of their borrowings from developed-country commercial banks and multilateral financial institutions. Larger firms in the power generation sector-developers of large IPP projects and NTPC - whose high capital requirements have required nondomestic finance for new, expanded, and modernized plants have been forced to adhere to beyond-compliance standards of environmental performance. As a result, they have progressed further than firms without foreign finance-for example, SEBs and the smaller IPP developers - in adopting more environmentally sound practices.

Finally, differences in corporate greening have been shaped by connectedness to regulatory pressure exercised by civil activists, community groups and NGOs. As in the case of enforcement, the high visibility, environmental impact, and signaling value of larger firms and projects have meant that they have tended to form the predominant focus of civil society activism. Within the power sector, for example, larger, high-profile IPP projects have been the subject of sustained campaigns by community groups and NGOs. Conversely, smaller IPP plants have largely escaped the attention of NGOs. To be fair, there is nothing new about citizen opposition, resistance, and action against industrial projects, and its existence cannot simply be ascribed to global influences (Shiva, and Jafri 1998). Yet the expansion of transnational activist networks has nevertheless increased "informal" regulatory pressures, particularly for TNCs, which have generally found themselves the subject of greater scrutiny from domestic and foreign NGOs. Mostly in response to these realities, certain TNCs (e.g., Ford) have purposely adopted higher environmental standards for their subsidiaries than comparable indigenously owned firms.

\section{Internal Resources and Capabilities}

A second set of factors which have contributed to heterogeneity in patterns of corporate environmentalism are firms' internal resources and capabilities. These include financial capabilities whose importance is starkly illustrated in the power sector where interfirm variations in corporate greening have closely mirrored variations in financial resources. The superior financial capabilities of NTPC and several of the larger IPP developers shows that they have been well-placed to invest 
in more efficient fossil-fueled technologies, which are invariably highly capitalintensive. These firms have also possessed the financial resources to design, implement, and maintain EMSs. The flipside is that power generators with weak finances - including many SEBs - have struggled to make investments in modernizing aging plants, or replacing them with new, more environment-efficient generating capacity. Their limited financial capabilities have also restricted SEBs' ability to upgrade, replace, or add end-of-technologies.

Financial capabilities have also played a role in the steel sector. An important reason why TISCO made more progress than SAIL in upgrading its plant to greater environment efficiency during the 1990s was TISCO's superior financial resources. Although both firms have been hampered by inadequate investment capital, the declining financial position of SAIL meant that the company's modernization drive effectively halted during the late 1990s.

It is not only financial capabilities that have differentiated firms' environmental investments. As evidenced by the environmentally superior technologies adopted by transnational vehicles manufacturers in the 1990s, technological capabilities have also been important. Through their regional and international networks of design, manufacturing, and assembly facilities, Indian subsidiaries of TNCs such as Ford and Hyundai had ready access to environment-efficient base-engine units, long before they were required by regulations. This meant that transnationals were far better placed to readily deploy beyond-compliance engines than their indigenous counterparts although, as explained below, understanding why they chose to use this technology requires an understanding of corporate strategy.

\section{Linking Resources and Incentives: Corporate Strategy}

I have sought to explain differences in corporate greening in terms of firms' exposure to external pressures, as well as their internal resources and capabilities. To complete the discussion, it is necessary to consider corporate strategy in more detail. Corporate strategies have predominantly been important since they have provided the link between external pressures and internal capabilities. Consistent with the resource-based perspective, internal resources have defined the corporate strategies available to, economically profitable for, and pursued by, domestic and foreign firms. Corporate strategies, in turn, have determined firms' market positioning, and therefore their exposure to external pressures, forces, and innovations.

Within the steel industry, for example, the well-developed financial and technological capabilities of larger firms such as TISCO and JVSL-or, more to the point, the conglomerates to which they belong - mean that they have been wellplaced to invest in modern, efficient technologies. Leveraging their superior resources and capabilities, these larger firms have pursued a differentiation strategy. Rather than specializing in low-value, commodity steels, they have focused their efforts on more profitable, high-quality steels. Because this involves participation in export markets or domestic markets with import competition, these firms have been exposed to a range of international influences, creating pressures for corporate greening and upward convergence in environmental behavior. Small-scale induction furnace producers have pursued a very different strategy. The majority of these firms lack well-developed financial or technological resources. Yet they have price 
advantages, owing to their access to low-cost resources (i.e., local scrap), labor, and technology. Small-scale steel firms have focused on supplying local and regional markets with comparatively low quality steels. In doing so, they have been insulated from many external forces promoting corporate greening among larger steel producers, restricting the scope of upward environmental convergence.

Resource-based strategies also contributed to differences in the environmental performance of firms in the automobile sector. Here, certain foreign multinationals entered the Indian market in the mid-1990s with advanced, beyond-compliance engine technology. As noted earlier, this was partly governed by cost, with many transnational vehicle manufacturers finding it cheaper to exploit cross-market economies of scale and scope by using standardized, environment-efficient engines rather than to engineer a dedicated compliance-only engine specifically for the Indian market. Equally important in transnational vehicle manufacturers deciding to transfer relatively new vehicle technology and designs was a strategic decision to exploit their superior technological resources for differentiation advantage. Unable to compete solely on cost with domestic firms, the local subsidiaries of foreign TNCs purposely deployed and marketed advanced vehicle technology, originating from their parent network. Among others, this included modern, environment-efficient engine designs, which appealed to consumer preferences for the latest, world-class technology and allowed transnational firms to command a price premium. As in the case of steel, a nonenvironmental corporate strategy had environmental implications.

Indigenous manufacturers also adopted a resource-based strategy-albeit of a different kind. With their competitive advantage rooted in manufacturing cheap, "low-tech" cars, domestically-owned firms sought to compete based on cost. In practice, this meant continuing with the production of established carburetor-based gasoline engines, rather than challenging transnationals by upgrading to more environmentally-sound direct injection equivalents. Although less advanced, such engines were cheaper to manufacture, allowing indigenous firms to undercut the Indian subsidiaries of transnational vehicle manufacturers. With the introduction of more stringent emissions regulations (especially Bharat stage-I and stage-II), domestic manufacturers were forced to abandon this low-tech strategy and upgrade their engine designs. Yet, for several years, the different resource-based strategies deployed by domestic and foreign firms were influential in differentiating the environmental performance of their products.

\section{Conclusions and Discussion}

According to several recent studies, firms in the rapidly industrializing economies of Asia and Latin America are increasingly adopting more environmentally sound technologies, organizational practices, and performances, although patterns of corporate greening remain "patchy" (Jenkins 2000; Ruud 2002; Utting 2002). This article aims to improve current understanding of these dynamics, offering a more completely specified account of emerging patterns of corporate environmentalism in developing countries. Previous work in this field has largely sought to explain corporate greening in terms of the presence of various drivers, and unevenness with reference to one of various constraints faced by firms. I expand on these proximate 
explanations of corporate greening, situating them within a broader theoretical framework of convergence, firm specificity, and heterogeneity.

Through a comparative analysis of firms in three sectors - automobiles, steel, and power-of the Indian economy, I attempt to show that the growth of corporate environmentalism is best understood in terms of cross-national convergence processes, whereby developments in environmentalism, environmental policies, technologies, and organizational practices in developed economies have influenced similar developments in developing countries. I suggest that the proximate drivers of corporate environmentalism have not arisen in a vacuum, but are the product of heightened international exposure, engagement, and interdependence. In making these arguments, I challenge the overt income determinism of the environmental Kuznets curve. The greening of industry, I suggest, is not just contingent on developing countries reaching a certain level of per capita income.

While not denying a role for economic growth, this study suggests that the most important factor in the recent emergence of corporate environmentalism in India has been increased exposure to nondomestic actors, innovations and pressures. Contrary to popular neoliberal narratives, these nondomestic influences did not simply result from "open markets" (OECD 1998). The genesis of corporate environmentalism in India took place against a backdrop of a closed, import-substituting, macroregulatory regime. Instead, corporate greening was kick-started indirectly by the country's growing engagement in international polity, politics, and policymaking. Participation in international environmental conferences, in particular, was instrumental in the domestic incorporation of global norms of environmentalism among political elites. These normative obligations, in turn, were the catalyst for several waves of environmental policymaking beginning in the early 1970s. Responding to these regulations, many industrial firms invested in a range of pollution control technologies in the last 20 years.

Without doubt, recent neoliberal reforms have significantly accelerated corporate greening in India. Opening markets, the involvement of transnational actors, and intensifying competition exposed firms directly to a range of competitive economic, coercive, and mimetic forces. Together, these have encouraged, forced, and induced firms to adopt a range of environmentally sound innovations. Equally important, neoliberal reforms increased the supply of environment-efficient technologies, and at a fraction of their original development costs. Largely on account of cross-market economies of scale, firms in India are acquiring "standardized" technologies that embody high levels of environmental performance at increasingly competitive prices.

Corporate greening received further impetus by increasing transnational contact, communication, and networking, which in exposing India's middle classes to international normative and mimetic influences, have underpinned the growth of modern ("Western") forms of environmentalism. Importantly, environmental demands from this politically influential group have intensified environmental pressure on the executive and judiciary, and raised the benchmark of expectations closer to those in developed economies. At the same time, new possibilities for transnational advocacy have re-scaled the spaces of corporate accountability (Mason 2005), creating incentives for affiliates and subsidiaries of TNCs in India to adhere to "global" standards of environmental performance. 
Uneven patterns of corporate greening in India indicate that external pressures, forces, and innovation dynamics have not led to homogeneity. Some firms have invested heavily in environmentally sound technologies, organizational practices and performances increasingly similar to their counterparts in developed economies. Yet others have made little or no progress toward corporate environmentalism. Central to understanding these differences are two factors. The first is variation in firms' exposure to external pressures for homogeneity, including international market processes, regulative forces and transnational coercive pressures. The second is firm internal resources and capabilities. Going beyond existing studies, I argue that internal resources are not just relevant in a reactive sense. While financial and technological resources clearly influence firms' ability to respond to external pressures, their importance runs deeper. In particular, resources and capabilities also define the availability, viability, and profitability of different corporate strategies, which can have significant environmental consequences by influencing technological, organizational, and policy choices. They also potentially influence firms' market positioning, and with it, their exposure to economic and institutional forces promoting homogeneity in technologies, practices, and performance.

What are the wider implications of this study? To begin with, the findings counter suggestions that globalization is inimical to sustainability in developing countries. If the Indian experience is generalizable, and there are few reasons to believe that it is not, increased communication, exchange, and integration internationally would appear to increase the demand for, and supply of, environmentally sound practices. In doing so, they provide a favorable context for the transfer and spread of corporate environmentalism beyond its historic core in developed economies, to a growing number of developing ones.

Yet such broad-brush optimism needs to be set against two important caveats. First, as already noted, corporate greening remains highly uneven. Indeed, the majority of firms continue to lag significantly their counterparts in developed countries, with few actual examples of where firms in India have caught-up. Second, heavily influenced by external developments, the brand of corporate environmentalism being adopted in India is situated mostly within the dominant paradigm of capitalist-friendly, hydrocarbon-based Western market environmentalism. To the extent that firms in India are acting as agents of environmental sustainability, they do so within the confines defined by environmentalism pioneered in many developed economies. There is little evidence of more "radical" versions of corporate environmentalism emerging in India, as advocated by several critics.

The study also has implications for theory. It suggests that economic and institutional theories of convergence offer useful insights into the international transfer and diffusion of corporate environmentalism. While economic theories of convergence have long been applied to understanding growing similarity on a crossnational basis, previous applications have often ignored associated environmental aspects. Yet this study reveals that the same dynamics that foster income convergence - transmission of competitive pressures via trade and FDI and the supply of more modern, advanced technology - also contribute much in explaining examples of upward convergence in environmental technologies and practices. Rational economic pressures, motives, and mechanisms appear to support the globalization of corporate environmentalism. At the same time, the study strongly 
indicates that any attempt to explain the growth corporate environmentalism in developing countries without considering institutional/sociological pressures would be incomplete. While rational economic theories provide (in)valuable insights into the dynamics of upward convergence, they fail to account for other important drivers of corporate greening. Most obvious, these include government environmental regulations, yet also mimetic dynamics that foster the uptake of various beyondcompliance organizational practices by indigenous firms.

Advancing on several previous institutionalist accounts, I show that sociological forces not only operate to create isomorphism in corporate environmentalism at the national level, but also at the international one. As interorganizational networks transcend national borders, institutional fields for corporate greening are becoming stretched across geographic space, promoting cross-national convergence in environmental norms, regulatory policies, and corporate environmental practices. While this article provides a preliminary examination of these globalizing dynamics, an important challenge for future work is to explore further their influence in advancing corporate sustainability in developing countries across a wider range of domestic contexts.

Acknowledgements I thank the countless individuals in India who kindly gave up their time to participate in this research. The research was supported by the UK's Economic and Social Research Council (ESRC) under Postdoctoral Fellowship Reference T026271127.

\section{References}

Argent N. A global model or a scaled-down version? Geographies of convergence and divergence in the Australian retail banking sector. Geoforum. 2002;33:315-34.

Athreye SS. Relative underdevelopment as a barrier to technological efficiency: a comparative study of ministeel plants in India and the UK. Mod Asian Stud. 1999;33:733-58.

Bennett CJ. Understanding ripple effects: the cross-national adoption of policy instruments for bureaucratic accountability. Governance. 1997;10:213-33.

Blackman A, Afsah S, Ratunanda D. How do public disclosure pollution control programs work? Evidence from Indonesia. Hum Ecol Rev. 2004;11:235-46.

Bode J-W, de Beer J, Blok K, Ellis J. An initial view on methodologies for emission baselines: iron and steel case study. In: OECD and IEA information paper. Paris: OECD/IEA; 2000.

Chandekar DA. A great leap forward in flat-rolled steel. Met Bull Mon. 1998;350:42-44.

Chandekar DA. Better times ahead? Met Bull Mon. 2000;350:34-40.

Christmann P, Taylor G. Firm self-regulation through international certifiable standards: determinants of symbolic versus substantive implementation. J Int Bus Stud. 2006;37:863-78.

Dasgupta N. Environmental enforcement and small industries in India: reworking the problem in the poverty context. World Dev. 2000;28:945-68.

Dasgupta S, Mody A, Roy S, Wheeler D. Environmental regulation and development: a cross-country empirical analysis. Oxf Dev Stud. 2001;29:173-87.

Delmas MA, Toffel MW. Stakeholders and environmental management practices: an institutional framework. Bus Strategy Environ. 2004;13:209-22.

DiMaggio PJ, Powell WW. The iron cage revisited: institutional isomorphism and collective rationality in organizational fields. Am Soc Rev. 1983;48:147-60.

Dore R, Lazonick W, O’Sullivan M. Varieties of capitalism in the twentieth century. Oxf Rev Econ Policy. 1999;15:102-20.

Dwivedi OP. India's environmental policies, programmes, and stewardship. Basingstoke: Macmillan; 1997.

Economy E. The river runs black: the environmental challenge to China's future. London: Cornell University Press; 2004. 
EIA. Annual energy review 2004. Washington, DC: Energy Information Administration; 2005.

EWEA. Wind power installed in Europe. Belgium: European Wind Energy Association; 2005.

EWEA. Wind power installed in Europe. Belgium: European Wind Energy Association; 2006.

Frank DJ, Hironaka A, Schofer E. The nation-state and the natural environment over the twentieth century. Am Soc Rev. 2000;65:96-116.

Garcia-Johnson R. Exporting environmentalism: US multinational chemical corporations in Brazil and Mexico. London: MIT Press; 2000.

Ghosh AK, Abbi YP. Clean coal technologies for Indian coals. Indian J Power River Dev. 2000;50:43-47.

Glasson J, Therivel R, Chadwick A. Introduction to environmental impact assessment: principles and procedures, process, practice and prospects. London: UCL Press; 1994.

Gong G, Keller W. Convergence and polarization in global income levels: a review of recent results of international technological diffusion. Res Policy. 2003;32:1055-79.

Govil KK. Electricity generation-Policy, technology and economy. New Delhi: Venus Publishing House; 1998.

Greenspan Bell R, Mathur K, Narain U, Simpson D. Cleaning the air: how Delhi broke the logjam on air quality reforms. Environment. 2004;46:22-39.

Grossman GM, Krueger AB. Economic growth and the environment. Q J Econ. 1995;110:353-77.

Grubb MJ, Hope C, Fouquet R. Climatic implications of the Kyoto protocol: the contribution of international spillover. Clim Change. 2002;54:11-28.

Guha R, Martinez-Alier J. Varieties of environmentalism: Essays North and South. London: Earthscan; 1997.

Gupta A, Yunus M. India and the WSSD (Rio + 10), Johannesburg: issues of national concern and international strategies. Curr Sci. 2004;87:37-43.

Haas PM. UN conferences and constructivist governance of the environment. Glob Gov. 2002;8:73-91.

Hettige H, Huq M, Pargal S. Determinants of pollution abatement in developing countries: evidence from South and Southeast Asia. World Dev. 1996;24:1891-904.

Hilton F. Later abatement, faster abatement: evidence and explanations from the global phaseout of leaded gasoline. J Environ Dev. 2001;10:246-65.

Hoffman AJ. From heresy to dogma: an institutional history of corporate environmentalism. Stanford: Stanford University Press; 2001. expanded ed.

Howes R, Skea J, Whelan B. Clean and competitive: motivating environmental performance in industry. London: Earthscan; 1997.

IISI. Steel: the foundation of a sustainable future. Sustainability report of the world steel industry. Brussels: International Iron and Steel Institute; 2005.

IISI. World steel in figures. Brussels: International Iron and Steel Institute; various years.

Jenkins R, editor. Industry and environment in Latin America. London: Routledge; 2000.

Jeppesen S, Hansen MW. Environmental upgrading of third world enterprises through linkages to transnational corporations: theoretical perspectives and preliminary evidence. Bus Strategy Environ. 2004;13:261-74.

Kher M. Coping with technological change. New Delhi: Response Books; 1997.

Kuik OJ, Nadkarni MV, Oosterhuis FH, Sastry GS, Akkerman AE. Pollution control in the South and North: a comparative assessment of environmental policy approaches in India and the Netherlands. New Delhi: Sage Publications India; 1997.

Levy DL, Kolk A. Strategic responses to global climate change: conflicting pressures on multinationals in the oil industry. Bus Polit. 2002;4:275-300.

Mason M. The new accountability: environmental responsibility across borders. London: Earthscan; 2005.

Matouq M. A case-study of ISO 14001-based environmental management system implementation in the People's Republic of China. Local Environ. 2000;5:415-33.

Mehra J. Steel: on the recovery path. In: Ravi N, editor. Survey of Indian industry. Chennai: Kasturi and Sons; 2003. p. 209-11.

Mendel PJ. International standardisation and global governance: the spread of quality and environmental management standards. In: Hoffman AJ, Ventresca MJ, editors. Organizations, policy and the natural environment. Stanford: Stanford University Press; 2002. p. 407-24.

Mercado A. Environmental assessment of the Mexican steel industry. In: Jenkins R, editor. Industry and environment in Latin America. London: Routledge; 2000. p. 218-44.

Mittal UK. Technology strategy for Indian steel industry. In: Proceedings of national seminar on Indian iron and steel industry: Vision 2012, 28-30 October 1996, at Kala Academy Complex, Campel, Panjim (Goa); 1996.

MNES. Annual report 2005-2006 New Delhi: Ministry of Non-Conventional Energy Resources; 2006. 
Mondt JR. Cleaner cars: the history and technology of emissions control since the 1960s. Warrendale, Pa.: Society of Automotive Engineers; 2000.

Mytton M, Lewis J. The world steel industry: an age of new technology and open markets. London: Financial Times Energy; 1997.

Najam A. Developing countries and global environmental governance: from contestation to participation to engagement. International Environmental Agreements. 2005;5:303-21.

Neumayer E, Perkins R. What explains the uneven take-up of ISO 14001 at the global level? A panel data analysis. Environ Plann A. 2004;36:823-39.

NTPC Environmental management 2006. Available from <http://www.ntpc.co.in/infocus/environment. shtml>; 2006.

OECD. Open markets matter: the benefits of trade and investment liberalization. Paris: OECD; 1998.

Office of the Deputy Commissioner of Iron and Steel. Comprehensive survey on induction furnace industry: a report (part-i). Calcutta: Joint Plant Committee; 1999.

Oliver C. Sustainable competitive advantage: combining institutional and resource-based views. Strategic Management Journal. 1997;18:697-713.

Peritore P. Third world environmentalism: case studies from the global South. Gainesville: University of Florida Press; 1999.

Perkins R. Electricity sector restructuring in India: an environmentally beneficial policy? Energy Policy. 2005;33:439-49.

Perkins R, Neumayer E. Europeanisation and the uneven convergence of environmental policy: explaining the geography of EMAS. Environ Plann C. 2004;22:881-97.

Perkins R, Neumayer E. The international diffusion of new technologies: a multitechnology analysis of latecomer advantage and global economic integration. Ann Assoc Am Geogr. 2005;95:789-808.

Peterlaf MA. The cornerstones of competitive advantage: a resource-based perspective. Strateg Manage J. 1993;14:179-91.

Potoski M, Prakash A. Regulatory convergence in non-governmental regimes? Cross-national adoption of ISO14001 certifications. J Polit. 2004;66:885-905.

Reppelin-Hill V. Trade and environment: an empirical analysis of the technology effect in the steel industry. J Environ Econ Manage. 1999;38:283-301.

Rock MT. Pollution control in East Asia: lessons for newly industrializing economies. Washington, DC: Resources for the Future; 2002.

Ruud A. Transnational corporations in India: are TNCs creating islands of environmental excellence in a sea of dirt? Bus Strategy Environ. 2002;11:103-18.

SAIL. Annual report 1998-99. Environmental Management Division, Steel Authority of India Ltd.; n.d.

SAIL. Annual report. Environmental Management Division, Steel Authority of India Ltd; various years.

Sawhney A. The new face of environmental management in India. Aldershot: Ashgate; 2004.

Sharma A, Roychowdhury A. Slow murder: the deadly story of vehicular pollution in India. New Delhi: Centre for Science and Environment; 1996.

Shin S. Economic globalization and the environment in China: a comparative case study of Shenyang and Dalian. J Environ Dev. 2004;13:263-94.

Shiva V, Jafri AH. Stronger than steel: Indian people's movement against the Gopalpur steel plant. The Ecologist. 1998;28:349-53.

SIAM. Viewpoint (quarterly newsletter of the Society of Indian Automobile Manufacturers) 2000;2:1.

Sorabjee H. An automotive history. Business India 1997;11-24 August.

Sorabjee H. Catalyst of change. Autocar India 2005;March:37-39.

Steger U. Environmental management systems: empirical evidence and further perspectives. Eur Manag J. 2000;18:23-37.

Tata Steel. Environmental performance report. Jamshedpur: Environmental management, Tata Steel; various years.

Tews K, Busch P-O, Jörgens H. The diffusion of new environmental policy instruments. Eur J Polit Res. 2003;42:569-600.

Utting P, editor. The greening of business in developing countries: rhetoric, reality, and prospects. London: Zed Books; 2002.

Venkataramani R. Japan enters Indian industry: the Maruti-Suzuki joint venture. New Delhi: Radiant Publishers; 1990.

Vogel D. Environmental regulation and economic integration. Journal of International Economics. 2000; 3:265-79. 
Warhurst A, Bridge G. Economic liberalisation, innovation, and technology transfer: opportunities for cleaner production in the minerals industry. Nat Resour Forum. 1997;21:1-12.

Richard Perkins is a lecturer in environmental geography in the Department of Geography and Environment, London School of Economics and Political Science. His research interests center on advancing understanding of globalization and environmental change, innovation diffusion, and policy implementation. 